\title{
NOTE
}

\section{Cloning and expression of a putative glycoprotein gene of channel catfish virus using baculovirus expression system}

\author{
Huseyin Kucuktas ${ }^{1}$, Yolanda J. Brady ${ }^{1, *}$, Sadik Tuzun ${ }^{2}$ \\ ${ }^{1}$ Department of Fisheries and Allied Aquacultures and \\ ${ }^{2}$ Department of Plant Pathology, Auburn University, Auburn, Alabama 36849, USA
}

\begin{abstract}
The 1035 base-pair (bp) open reading frame 59 (ORF59) of channel catfish virus (CCV) codes for an abundant hydrophobic membrane glycoprotein considered to be the major envelope glycoprotein of the virus. The ORF59 gene of $\mathrm{CCV}$ was cloned into the baculovirus genome by site-specific transposition and expressed in Spodoptera frugiperda cells (Sf9 cells). Expressed protein could be recognized by polyclonal antibody against $\mathrm{CCV}$ and appeared to have the same electrophoretic mobility as native protein. Crude lysates of Sf 9 cells infected with recombinant baculovirus containing ORF59 gene inhibited plaque formation of CCV on channel catfish ovary cells.
\end{abstract}

KEY WORDS: Channel catfish virus - Glycoprotein - Baculovirus expression

Channel catfish virus (CCV, Ictalurid Herpesvirus 1) is a highly contagious pathogen of channel catfish that causes significant economic losses in the catfish industry. It was first isolated by Fijan (1968) and classified as a herpesvirus based on its morphology (Wolf \& Darlington 1971). This virus was placed in the Alphaherpesvirinae subfamily because of its short replication cycle and rapid destruction of cells in vitro (Roizman 1990).

CCV possesses a dsDNA genome, which is surrounded by an enveloped nucleocapsid (Wolf $\&$ Darlington 1971). The 134 kilo base-pair (kbp) linear genome of the virus encodes 77 genes, and 14 of these genes are in repeated regions (Chousterman et al. 1979, Dixon \& Farber 1980, Davison 1992). Some of these genes are believed to be enzyme coding genes based on either amino-acid sequence comparisons or actual enzymatic studies (Lacasa 1990, Harrison et al.

- Addressee for correspondence.

E-mail: ybrady@acesag.auburn.edu
1991, Hanson \& Thune 1993). Although virion and capsid morphology of $\mathrm{CCV}$ and other herpesviruses are similar, comparison of CCV genes with other known herpesvirus genes revealed that it is premature to establish a common evolutionary origin of CCV and other herpesviruses (Davison 1992, Davison \& Davison 1995).

According to sequence and mass spectrometric data, the $1035 \mathrm{bp}$ open reading frame 59 (ORF59) encodes an abundant $38 \mathrm{kDa}$ envelope glycoprotein, which is detectable in at least 5 forms. Its structure and orientation suggest that it forms an external loop containing 3 potential glycosylation sites on the surface of the virion, making ORF59 gene products the main candidates for major antigenic determinants of $\mathrm{CCV}$ (Davison \& Davison 1995) and therefore making them. potentially useful as vaccines. Sequence analysis showed that CCV lacks any genes with predicted amino-acid sequence homology to envelope glycoproteins of mammalian and avian herpesviruses (Davison 1992, Davison \& Davison 1995).

Channel catfish produce an immune response to $\mathrm{CCV}$, and neutralizing antibodies can be detected as early as $1 \mathrm{wk}$ after experimental injection. In experimentally infected fish, antibodies against CCV were detected at maximum levels by serum neutralization tests 9 wk after infection (Plumb 1973, Heartwell 1974). Also, antibodies against CCV could be detected over 2 yr with low neutralization indexes in both naturally and experimentally infected fish (Plumb 1973). Although catfish do not show a constant humoral response, there may be some memory response to CCV (Heartwell 1974).

In the past, different approaches were taken to develop a vaccine against CCV. Significant protection was observed when an attenuated strain of CCV was administered as bath treatment (Noga \& Hartmann 
1981, Walczak et al. 1981). Subsequent studies showed that the attenuated strain used in these studies had a deletion mutation in ORF50 whose product was a putative secreted glycoprotein (Vanderheijden et al. 1996). Similarly, a subunit vaccine prepared from the envelope fraction of CCV increased the survival rate of both eggs and fry challenged with lethal doses of CCV (Awad et al. 1989). Recently, Zhang \& Hanson (1995) reported preliminary studies on a live, thymidinekinase mutant CCV vaccine. Previous vaccines were delivered as either intraperitoneal injection or immersion bath, but the first vaccine using attenuated CCV retained a degree of virulence, and the subunit vaccine required the purification of envelope from virion.

The baculovirus-infected insect cell expression system is a common way to produce recombinant proteins because of its easy manipulation and high recombinant protein yields. Most post-translational modifications that occur in eukaryotic cells also take place in insect cell systems. Although the majority of studies to date suggest that this system is capable of processing only simple type oligosaccharides (Jenkins et al. 1996), complex $\mathrm{N}$-linked glycan processing in insect cells was also reported (O'Reilly et al. 1992). Proper glycosylation of expressed proteins is highly crucial for their immunogenic activity especially when they are used as vaccines (Osterreider et al. 1994, Wagner et al. 1996). Glycoprotein genes of several other herpesviruses and other fish viruses have been successfully cloned and expressed in baculovirus expression systems as well as prokaryotic and eukaryotic expression systems (O'Reilly et al. 1992, Lecocq-Xhonneux et al. 1994).

In the present research, the entire ORF59 gene, encoding a putative glycoprotein of $\mathrm{CCV}$, was manipulated and cloned into a baculovirus by site-specific transposition (Luckow et al. 1993). Recombinant protein expressed in baculoviruses was analyzed by SDSPAGE and Western blot analysis. Time course experiments were carried out to determine the optimum harvest time. Also, in vitro effects of recombinant protein on CCV-cell interactions were investigated.

Materials and methods. Virus and cells: Channel catfish ovary (CCO) cells (Bowser \& Plumb 1980) were grown in $850 \mathrm{~cm}^{2}$ roller bottles at $30^{\circ} \mathrm{C}$ in Eagle's minimum essential medium (EMEM) supplemented with $10 \%$ fetal bovine serum (FBS) (Atlanta Biologicals, Norcoss, Georgia). Channel catfish virus ATCC type strain (ATCC VR-665) was propagated in CCO cells at $30^{\circ} \mathrm{C}$ by infecting monolayers of 4 collagen (Sigma Chemicals, St. Louis, Missouri) coated roller bottles at a multiplicity of infection (MOI) of 1. After all cells were detached from the surface, cultures were frozen at $-80^{\circ} \mathrm{C}$ and thawed 3 times at $37^{\circ} \mathrm{C}$ to release virus. Cell debris was removed by low speed centrifugation, and, after virus titer was determined by the end point dilution method (Reed \& Muench 1938), the medium was stored at $-80^{\circ} \mathrm{C}$. CCV DNA was purified by the procedure described in van Santen (1991), with a minor modification. Pelleting the viral DNA through a $\mathrm{NaCl}$ cushion was omitted from the procedure. DNA samples were aliquoted and stored at $-20^{\circ} \mathrm{C}$

Spodoptera frugiperda cells (Sfg) were grown in suspension and monolayer cultures at $28^{\circ} \mathrm{C}$ in serum free medium, SF900 II SFM (GIBCO/BRL). Wild type Autographa californica nuclear polyhedrosis virus (AcMNPV) L1 strain was kindly provided by L. K. Miller, University of Georgia Athens, Georgia.

Construction of recombinant plasmid and baculoviruses: To construct pCCV59B, CCV DNA was digested with BamHI and KpnI to recover a 2563 bp BamHI fragment containing the full length ORF59, and this fragment was cloned into the BamHI site of pUC19 (GIBCO/BRL). To remove flanking sequences from ORF59, pCCV59B was digested with BanII and the 1385 bp fragment containing ORF59 was sub-cloned into the Smal site of pUC19, yielding plasmid pCCV59-1. The BamHI/ECoRI fragment containing ORF59 from plasmid pCCV59-1 was inserted into the multiple cloning site, downstream to the polyhedrin promoter, of the donor plasmid pFASTBAC1 (GIBCO/ BRL) and designated as pFB591. The size and orientation of the insert in each cloning step were confirmed by at least 3 restriction enzyme digestions.

Transposition: Transposition was accomplished essentially by procedures outlined in the instruction manual provided by the supplier of BAC-TO-BAC Baculovirus Expression System (GIBCO/BRL). Briefly, competent Escherichia coli DH10BAC cells carrying the tetracycline ${ }^{r}$ helper plasmid (pMON7124) and a kanamycin ${ }^{\mathrm{r}}$, LacZ $\alpha^{+}$bacmid (bMON14272) (Luckow et al. 1993) were heat-shock transformed with recombinant donor plasmid pFB591 containing ORF59 gene downstream to the polyhedrin promoter. Positive colonies were selected on Luria agar (LB) plates containing tetracycline, kanamycin, and gentamicin as selective antibiotics. X-gal (5-bromo-4-chloro-3-indolyl$\beta$-D-galactosidase) or Bluo-gal (5-bromo-3-indoly]- $\beta$ D-galactosidase) and IPTG (isopropylthio- $\beta$-galactosidase) were used for color selection. As a positive control, donor plasmid pFASTBAC-gus (GIBCO/BRL) containing the GUS gene after the polyhedrin promoter was used to monitor transposition and protein expression. Plates were incubated at $37^{\circ} \mathrm{C}$ for more than $24 \mathrm{~h}$ and white colonies were streaked on fresh LB plates containing the same antibiotics and inducers. White gentamicin ${ }^{\mathrm{r}}$, tetracycline ${ }^{\mathrm{r}}$, and kanamycin ${ }^{\mathrm{r}}$ colonies carrying helper plasmid and recombinant bacmid containing either ORF59 or GUS gene were selected and bacmid DNA was isolated using a modified alkaline-lysis method according to the manufac- 
turer's instructions. Recombinant bacmids were identified with polymerase chain reaction (PCR) using M13/pUC -forward and -reverse primers as described in Donahue (1995).

Transfection of $\mathrm{Sf} 9$ cells with recombinant bacmids: Sf9 cells were transfected with $5 \mu$ of crude bacmid DNA ( 2 to $4 \mu \mathrm{g} \mathrm{ll}^{-1}$ DNA) by liposome mediated transfection using CELLFECTIN reagent (GIBCO/BRL). After incubation at $28^{\circ} \mathrm{C}$ for 48 to $72 \mathrm{~h}$, medium was collected, clarified by low-speed centrifugation and stored at $-80^{\circ} \mathrm{C}$. Recombinant viruses containing ORF59 gene were designated as BAC51, BAC52, and BAC53 and viruses containing the GUS gene were designated as BACgus. Only BAC52 was used in subsequent experiments, and $\mathrm{BAC} 51$ and $\mathrm{BAC} 53$ were kept as back-up stocks.

Recombinant protein production: Sf 9 cells grown either in suspension cultures or monolayers were infected with supernatants from transfection experiments, at an MOI of 0.01 to propagate stock recombinant virus, and subsequently this stock virus was used to generate $500 \mathrm{ml}$ of infected cell supernatants for use in recombinant protein production (King \& Possee 1992). $\beta$-Glucuronidase expression of BACgus was monitored on Sf 9 cells infected with BACgus by adding $5 \mu \mathrm{l}$ of $2 \mathrm{mg}$ $\mathrm{ml}^{-1}$ solution of $\mathrm{X}$-gluc (5-bromo-3-indolyl- $\beta$-D-glucorinidase) to $50 \mu \mathrm{l}$ of cell-free supernatant. To reduce proteolytic activity of lysed cells, $1 \%$ FBS was added to the cultures at $48 \mathrm{hpi}$. The cells were harvested $3 \mathrm{~d}$ post-infection by low-speed centrifugation. After 2 washings with phosphate buffered saline (PBS) $(\mathrm{pH} 6.2)$, cell pellets were stored at $-80^{\circ} \mathrm{C}$ until use. Negative controls were prepared using wild-type baculovirus (AcMNPV L1 strain) or mock infected Sf9 cells.

SDS-PAGE and Western blot analysis: For time course experiments, Sf9 cells infected with recombinant or wild-type baculovirus at an MOI of 5 were harvested at 24,48, 72 and $96 \mathrm{~h}$ post-infection (hpi). Cells were lysed with NP-40 lysis buffer $(50 \mathrm{mM}$ Tris- $\mathrm{HCl}$, $\mathrm{pH} 8.0 ; 150 \mathrm{mM} \mathrm{NaCl} ; 1 \% \mathrm{NP}-40$ ) containing protease inhibitor cocktail (PMSF [phenylmethylsulfonyl fluoride], $100 \mu \mathrm{g} \mathrm{ml}^{-1}$; pepstain, $1 \mu \mathrm{g} \mathrm{ml}^{-1}$; and leupeptin, $1 \mu \mathrm{g} \mathrm{ml}^{-1}$ ). A $10 \mu \mathrm{l}$ portion of supernatant was denatured by boiling prior to electrophoresis in a $10 \%$ SDSpolyacrylamide gel (Laemmli 1970). Proteins were visualized by staining with either Coomassie blue or silver staining. For Western blot analysis, proteins resolved in $10 \%$ SDS-polyacrylamide gels were electro-transferred onto nylon membranes (Magna, MSI, Westboro, Massachusetts), then the membranes were incubated in primary antibody buffer ( $2.5 \%$ non-fat dry milk in TBS) containing 1:1000 dilution of goat anti-CCV polyclonal serum (Plumb 1981). Alkaline-phosphatase conjugated mouse anti-goat immunoglobulin monoclonal antibodies (Sigma Chemicals) diluted 1:50000 in secondary antibody buffer (2.5\% non-fat dry milk in TBS) were added to membranes, and proteins were visualized by using a substrate consisting of alkaline phosphatase buffer (100 mM Tris base $[\mathrm{pH} 9.0] ; 100 \mathrm{mM} \mathrm{NaCl}$, $10 \mathrm{mM} \mathrm{MgCl}$ ) containing NBT (nitro blue tetrazolium) $\left(0.3 \mathrm{mg} \mathrm{ml}^{-1}\right.$ ) and BCIP (5-bromo-4-chloroindoxyl phosphate) $\left(80 \mu \mathrm{g} \mathrm{ml^{-1 }}\right)$.

Effects of expressed protein on plaque production by $\mathbf{C C V}$ on $\mathrm{CCO}$ cells: $\mathrm{CCO}$ cells were grown in 6 -well plates in EMEM at $30^{\circ} \mathrm{C}$ overnight. The next day the medium was removed and cells were treated for $1 \mathrm{~h}$ at room temperature with Hanks' balanced salt solution (HBSS) containing $2 \mu \mathrm{g} / 100 \mu \mathrm{l}$ total proteins of BAC52 or wild-type baculovirus infected insect cells in replicates of 5. Equal amounts of proteins from uninfected Sf9 cells were also used as control. Total protein samples were prepared from BAC52 or wild-type baculovirus infected or uninfected Sf9 cells using the method described by Wang et al. (1996). Protein concentrations were determined by a protein assay kit (Bio-Rad, Hercules, California) according to Bradford (1976). All plates were incubated at room temperature for $1 \mathrm{~h}$ with gentle shaking. Then, the protein solution was replaced with either $10050 \%$ tissue culture infective dose (TCID 50 ) CCV ATCC type strain or the same dose of a CCV field isolate (Southeastern Cooperative Fish Disease Laboratory, Case No.: AL-94-123) in HBSS. After an incubation period of $1 \mathrm{~h}$ at $30^{\circ} \mathrm{C}$ with gentle shaking, each well was washed 2 times with HBSS, and $2 \mathrm{ml}$ of agarose overlay $11 \%$ low melting point agarose in EMEM supplemented with $2 \%$ FBS) was added to each well. Plates were incubated at $30^{\circ} \mathrm{C}$ until the number of plaques did not change for 2 consecutive days. Infected cells were then fixed with $20 \%$ formaldehyde and stained with $0.5 \%$ crystal violet in $95 \%$ ethanol and plaques formed by both viruses in the presence and absence of ORF59 protein were counted.

Results. Removal of 5' flanking sequences from ORF59: The 2563 bp BamHI fragment of CCV DNA containing the 1035 bp ORF59 was altered by removing 745 nucleotides from 5' and 420 nucleotides from 3' flanking regions by a 2 -step cloning strategy. The resulting plasmid pCCV59-1 contained the full length ORF59 gene with an extra 74 and 295 nucleotides at the $5^{\prime}$ and $3^{\prime}$ ends, respectively. EcoRI-BamHI fragment containing ORF59 of plasmid pCCV59-1 was subcloned downstream to the polyhedrin promoter in donor plasmid pFASTBAC1. All plasmids were subjected to restriction analysis with 3 enzymes to confirm that each plasmid contained the correct size and orientation of insert (data not shown).

Transposition of ORF59 into the baculovirus genome and identification of recombinant bacmids: The donor plasmid transposed the gene fragment containing 


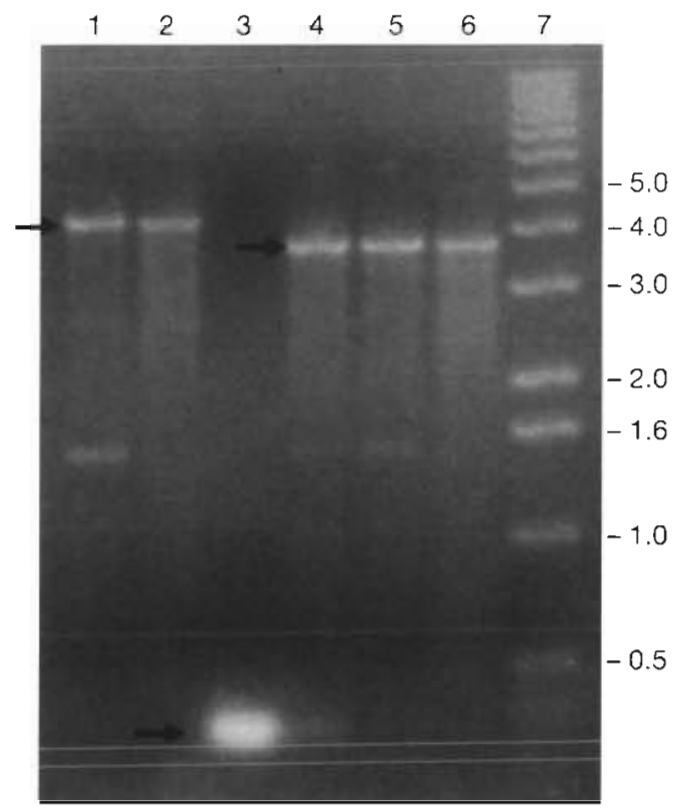

Fig. 1 PCR amplification of transposed DNA fragment containing ORF59 from bacmid DNA preparations. After transposition of DNA fragments containing either ORF59 or GUS gene along with the gentamicin resistance marker gene into modified bacmid, crude bacmid DNA isolated from white and blue colonies was amplified with pUC/M13 primers as described in 'Materials and methods' An aliquot of $10 \mu \mathrm{l}$ from each PCR reaction was analyzed on a $0.7 \%$ agarose gel. Lanes: 1 and 2, bacmid DNA containing GUS gene; 3, nonrecombinant bacmid DNA; 4, 5 and 6, bacmid DNA containing ORF59 gene; 7, $1 \mathrm{kbp}$ DNA size marker. Major amplification products from each bacmid preparation are indicated by arrows. Fragment sizes of molecular weight markers shown are in $\mathrm{kbp}$

ORF59 (pCCV59-1) to the attTn7 target site on the composite bacmid in Escherichia coli DH10BAC after heat-shock transformation of competent cells. Amplification of expected size fragments from recombinant bacmid DNA demonstrated a successful transfer of the gene into the composite bacmid by site-specific transposition (Fig. 1, lanes 4 to 6). The donor plasmid alone transferred a $2.4 \mathrm{kbp}$ fragment to the att $\operatorname{Tn} 7$ target site on the composite bacmid (Donahue 1995). Since the amplified product was $3.8 \mathrm{kbp}$ in size, the remaining $1.4 \mathrm{kbp}$ fragment would represent the ORF59 gene. Amplification of non-recombinant bacmid DNA gave a 325 bp fragment as demonstrated previously by Donahue (1995) (Fig. 1, lane 3). Similarly, from recombinant bacmid DNA carrying the $\beta$-glucuronidase gene (1.85 kbp) a $4.25 \mathrm{kbp}$ fragment was amplified (Fig. 1, lanes 1 and 2).

Transfection and protein expression analysis: Recombinant baculoviruses BAC51, BAC52, BAC53 and BACgus were generated by site-specific transposition in competent Escherichia coli DH10BAC. To monitor transposition and protein expression, BACgus infected Sf 9 cells were stained for $\beta$-glucorunidase activity in situ (data not shown).

Heterologous expression of the putative glycoprotein gene was determined by SDS-PAGE followed by silver staining and Western blot analysis of crude lysates of Sf9 cells infected either with BAC52, BACgus or wild-type baculoviruses. Total lysates of Sf9 cells infected with BAC 52 harvested at 48 hpi and analyzed by SDS-PAGE contained bands that were not present either in wild-type virus or mock infected cells (Fig. 2, lanes 2 to 4 ). Though a single band representing the putative glycoprotein in cell lysates infected with recombinant baculoviruses was seen on silver stained gels (Fig. 2, lane 4), a range of bands from 37 to $40 \mathrm{kDa}$ were visualized on Western blots. A $38 \mathrm{kDa}$ band reacted strongly with anti-CCV serum in samples harvested at $48 \mathrm{hpi}$; however, the mobility of this band was increased in samples harvested at 72 and 96 hpi (Fig. 3, lanes 2 to 5). Based on nucleotide sequence data, the protein product of ORF59 is proposed to be composed of 345 amino-acid residues with a $38.4 \mathrm{kDa}$ molecular mass (calculated value). Finally, we evaluated the in vitro activity of expressed proteins by determining whether the expressed proteins have an

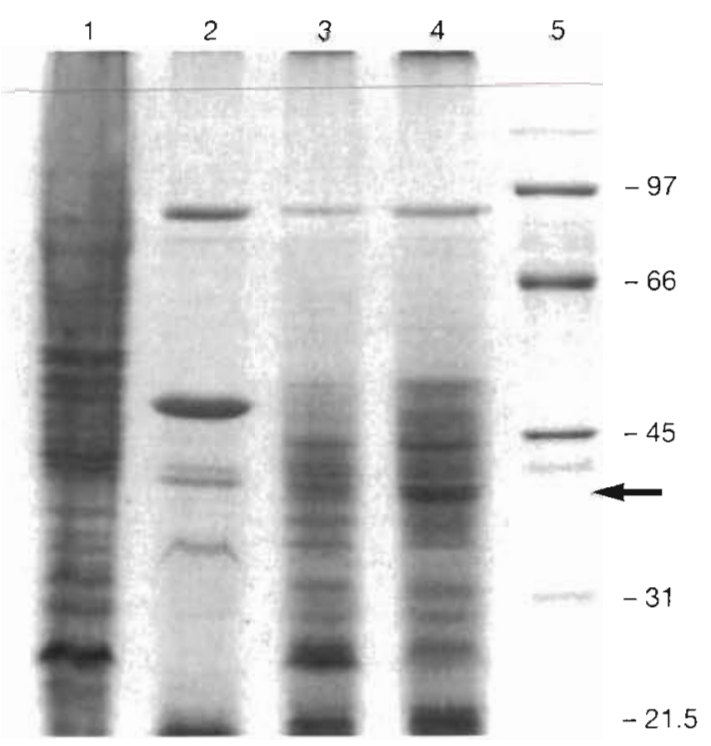

Fig. 2. SDS-PAGE analysis of ORF59 gene expression in recombinant baculovirus BAC52 infected. Sf 9 cells. $1 \times 10^{6}$ Sf 9 cells were infected with BAC52, BACgus, or wild-type baculovirus for $1 \mathrm{~h}$, and total cell lysates collected at $48 \mathrm{hpi}$ were subjected to SDS-PAGE ( $10 \%$ polyacrylamide gel). Resolved proteins were fixed and stained with. silver. As a control, total lysates from mock infected $\mathrm{Sf} 9$ cells were used. Lanes: 1 , mock infected Sf9 cell lysate ${ }_{i} 2$, wild-type baculovirus infected Sf9 cell lysates: 3, BACgus infected Sf9 cell lysates; 4, BAC52 infected Sf9 cell lysates; 5, molecular weight size markers. Expressed ORF59 gene product is marked by an arrow. Molecular weights are shown in $\mathrm{kDa}$ 


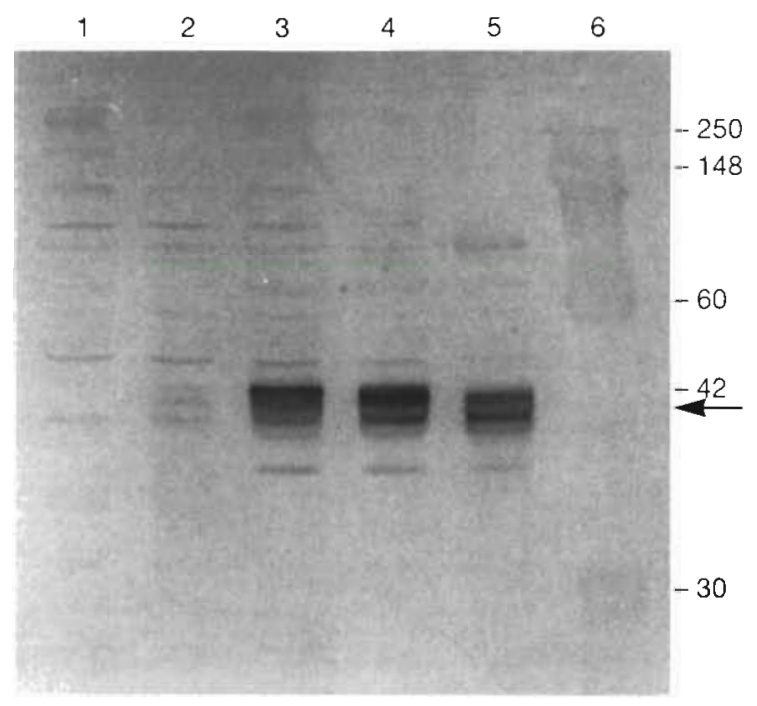

Fig. 3. Immunoblot analysis of ORF59 gene expression in recombinant baculovirus BAC52 infected Sf 9 cells. Sf 9 cells $(1 \times$ $10^{6}$ well) were infected with recombinant baculovirus BAC52 and total cell lysates were subjected to SDS-PAGE (10\% polyacrylamide gel). Resolved proteins were electro-transferred onto nylon membranes, probed with a goat anti-CCV polyclonal antiserum, and complexes were detected as described in 'Materials and methods'. As a control, total lysate from mock infected Sf9 cells at the first time point was used (24 hpi). Lanes: 1, mock infected Sf 9 cell lysate; $2,3,4$ and 5 , BAC52 infected Sf9 cell lysates, processed at 24, 48, 72 and $96 \mathrm{hpi}$; , molecular weight marker. Arrow: position of expressed product of ORF59 gene during the time course experiment. Molecular weights are shown in $\mathrm{kDa}$

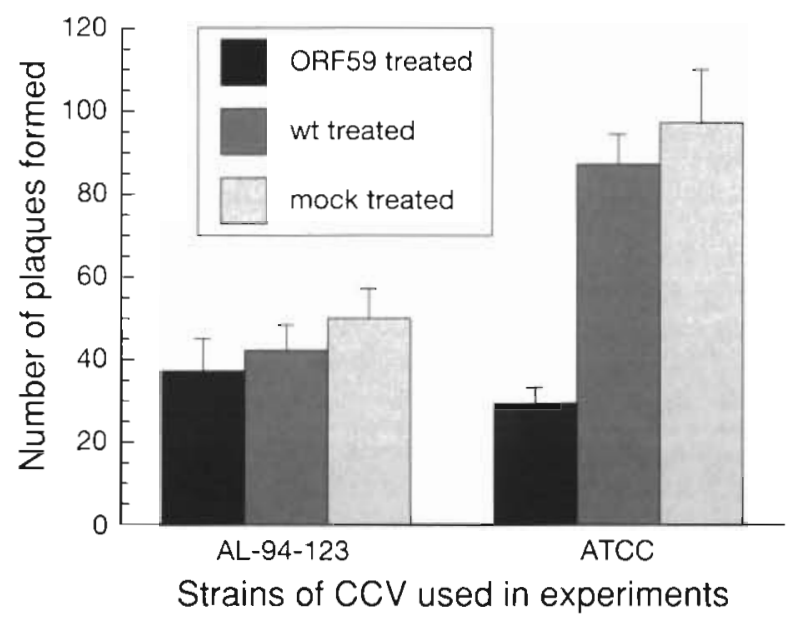

Fig. 4. Effect of BAC52 infected Sf9 total cell extracts on plaque formation of 2 channel catfish viruses on CCO cells. $\mathrm{CCO}$ monolayers were treated with $2 \mu \mathrm{g} / 100 \mu \mathrm{l}$ of BAC52 or wild-type (wt) baculovirus (AcMNPV L2 strain) or mock infected Sf9 cell extracts and infected with 100 TCID $_{50}$ of either ATTC type strain or a field strain of CCV (AL-94-123). Effect of Sf9 cell extracts on plaque formation is given as the mean \pm standard error of the number of plaques formed by ATCC or case (AL-94-123) CCV in 5 wells effect on infectivity of CCV on CCO cells. When CCO monolayers were treated with total cell extracts from Sf9 cells infected with BAC52, infection with CCV type strain resulted in $67 \%$ reduction in plaque formation (Fig. 4), compared to CCO monolayers treated with extracts of wild-type baculovirus infected Sf9 cells. On the other hand, treatment of CCO cells with the same extracts, followed by infection with a field isolate of $\mathrm{CCV}$, resulted in only $12 \%$ reduction in plaque formation.

Discussion. The lack of sequence homology between $\mathrm{CCV}$ and other well-known herpesviruses opens a wide area to explore the initial molecular events in CCV infection. Most mammalian and avian herpesviruses are known to have a series of glycoproteins responsible for attachment, entry and cell to cell transmission of virus (Spear 1993, Pereira 1994). Based on published DNA sequence of CCV (Davison 1992), we have cloned and expressed a putative glycoprotein of CCV in a baculovirus system. The apparent molecular weight of the baculovirus expressed protein observed from immunoblots is both similar to that observed in $\mathrm{CCV}$ itself and to that calculated from the computer-deduced amino-acid sequence data (Davison \& Davison 1995). The major envelope glycoprotein of CCV is encoded by ORF59, and according to mass spectrometric data it is present in at least 5 different forms (Davison \& Davison 1995). In our studies, Western blot analysis suggested that expressed ORF59 protein is a multiple-sized pratein (see Fig. 3). It is unlikely that these proteins could be the degraded products of the same protein, because the expressed protein is also multiple sized at $24 \mathrm{~h}$ time point (Fig. 3, lane 2). However, one could not rule out an increased proteolytic activity as the cell culture senesces, resulting in smaller protein products that may cross-react with antibody. Furthermore, the ability of CCV-specific sera to recognize insect cell expressed ORF59 product clearly indicated that the protein encoded by ORF59 is a major antigenic protein of the CCV.

In baculovirus expression systems, the deletion of $5^{\prime}$ non-coding sequences is desirable because this results in higher levels of expression of foreign genes (Hills \& Crane-Robinson 1995). Although our SDS-PAGE gels stained either with Coomassie blue or silver staining did not demonstrate high levels of expression of the recombinant glycoprotein, serum specific for $\mathrm{CCV}$ detected multiple bands in recombinant baculovirus infected Sf 9 cell lysates. Low levels of expression could be attributed to the presence of the 87 nucleotides before the start codon, which may have influenced the expression level of ORF59 gene.

Accurate glycosylation of expressed proteins is crucial in the secondary and tertiary structure of pro- 
tein (Osterreider et al. 1994, Baranowski et al. 1995, Wagner et al. 1996). The complexity of oligosaccharide moieties on the protein may influence its biological properties, such as enzymatic activity of the protein (Nimtz \& Conradt 1991) or the recognition by an antibody (Doms et al. 1993, Baranowski et al. 1995). Although insect cells lack some of the enzymes involved in complex glycosylation patterns known to be present in eukaryotic cells (Jenkins et al. 1996, Wagner et al. 1996), biologically active recombinant glycoproteins can be produced by insect cells. Nevertheless, time course experiments of BAC52 infected Sf9 cells indicate that whatever the complexity of glycosylation, recombinant protein could be detected by neutralizing sera (Fig. 3, lanes 3 to 5 ). There are 5 potential N-linked glycosylation sites on the ORF59 gene product (Davison 1992), and currently there is no information available on the presence and complexity of the glycosylation profile of ORF59 gene product. Several herpesviruses initially bind to a cell-surface receptor in early events in their infectivity (Spear 1993). These receptors are yet to be discovered in the case of CCV. The lack of any homology between CCV genes and other herpesvirus genes poses difficulty in elucidating proteins responsible for $\mathrm{CCV}$ attachment, penetration, and entry into host cells. In our studies, we have demonstrated that the ORF59 gene products influence early interactions between CCV and CCO cells. Reduction of the number of plaques produced on $\mathrm{CCO}$ monolayers treated with recombinant baculovirus infected crude cell lysates suggests that this glycoprotein may be involved in attachment of virions to their cellular receptors.

The attenuated V60 strain of CCV has a large deletion in the ORF50 gene possibly coding for a glycoprotein (Vanderheijden et al. 1996). In addition to this large deletion in ORF50, the same investigators noted several point mutations in the V60 strain genome. Our cloned ORF59 gene source is the ATCC type strain $\mathrm{CCV}$, which has been maintained on cell culture since its first deposition to the American Tissue Type Collection (ATTC) (Wolf \& Darlington 1971). Less reduction of the number of plaques on $\mathrm{CCO}$ monolayers infected with the field strain of CCV could possibly be explained by mutation of the ORF59 gene of ATCC type strain $\mathrm{CCV}_{\text {i }}$ however, only direct sequencing of the ORF59 gene of field strains of CCV would verify this.

In conclusion, this is the first report showing that $\mathrm{CCV}$ possesses a glycoprotein which is recognized by a polyclonal antibody. Expressed protein partially inhibits the early events taking place between $\mathrm{CCV}$ and $\mathrm{CCO}$ cells but this inhibition may be strain specific.
Acknowledgements. We thank Vicky van Santen, John Liu, and John Grizzle for critical reviews of the manuscript. This work was supported by U.S. Fish and Wildlife Project No. 533592. This is publication 8-975837 of Alabama Agricultural Experiment Station, Auburn University, Auburn, Alabama.

\section{LITERATURE CITED}

Awad MA, Nusbaum KE, Brady YJ (1989) Preliminary studies of a newly developed subunit vaccine for channel catfish virus disease. J Aquat Anim Health 1:233-237

Baranowski E, Dubuisson J, van Drunen Littel-van den Hurk S, Babiuk AL, Michel A, Pastoret P, Thiry E (1995) Synthesis and processing of bovine herpesvirus-1 glycoprotein $\mathrm{H}$ Virology 206:651-654

Bowser PR, Plumb JA (1980) Fish cell lines: establishment of a line from ovaries of channel catfish. In Vitro 16:365-368

Bradford MM (1976) A rapid and sensitive method for quantitation of microgram quantities of protein utilizing the principle of protein-dye binding. Anal Biochem 72:248-254

Chousterman S, Lacasa M, Sheldrick P (1979) Physical map of the channel catfish virus genome: location of sites for restriction endonucleases ECoRI, HindIII, HpaI, and XbaI, J Virol 31:73-85

Davison AJ (1992) Channel catfish virus: a new type of herpesvirus. Virology 186:9-14

Davison AJ, Davison MD (1995) Identification of structural proteins of channel catfish virus by mass spectrometry. Virology 206:1035-1043

Dixon RAF, Farber FE (1980) Channel catfish virus: physicochemical properties of the viral genome and identification of viral polypeptides. Virology 103:267-278

Doms RW, Lamb RA, Rose JK, Helenius A (1993) Folding and assembly of viral membrane proteins. Virology 193: 545-562

Donahue RA Jr (1995) Use of PCR to identify recombinant bacmid clones from the BAC-TO-BAC system. Focus 17 : $101-102$

Fijan NN (1968) Progress report on acute mortality of channel catfish fingerlings caused by a virus. Off Int Epizoot Bull 69:1167-1168

Hanson LA, Thune RL (1993) Characterization of thymidine kinase encoded by channel catfish virus. J Aquat Anim Health 5:199-204

Harrison PT, Thompson R, Davison AJ (1991) Evolution of herpesvirus thymidine kinases from cellular deoxycytidine kinase. J Gen Virol 72:2583-2586

Heartwell CM (1974) The immune response of channel catfish (Ictalurus punctatus) to a naturally pathogenic bacterium and virus. PhD dissertation, Colorado State University, Fort Collins

Hills D, Crane-Robinson C (1995) Baculovirus expression of human basic fibroblast growth factor from a synthetic gene: role of the Kozak consensus and comparison with bacterial expression. Biochim Biophys Acta 1260:14-20

Jenkins N, Parekh RB, James DC (1996) Getting the glycosylation right: implications for the biotechnology industry. Nature Biotechnol 14:975-981

King PA, Possee RD (1992) The baculovirus expression sys tem: a laboratory guide. Chapman \& Hall, London, p 1-229

Lacasa M (1990) A protein-kinase related gene within the channel catfish herpesvirus genome. Nucleic Acids Res 18:3050

Laemmli UK (1970) Cleavage of structural proteins during the assembly of the head of bacteriophage T4. Nature 227 : $680-685$ 
Lecocq-Xhonneux F, Thiry M, Dheur l, Rossius M, Vanderheijden N, Martial J, de Kinkelin P (1994) A recombinant viral haemorrhagic septicaemia virus glycoprotein expressed in insect cells induces protective immunity in rainbow trout. J Gen Virol 75:1579-1587

Luckow VA, Lee SC, Barry GF, Olins PO (1993) Efficient generation of infectious recombinant baculoviruses by sitespecific transposition-mediated insertion of foreign genes into a baculovirus genome propagated in Escherichia coli. J Virol 67:4566-4579

Nimtz M, Conradt HS (1991) Oligosaccharide structures of glycoproteins from recombinant mammalian cell lines. In: Conradt HS (ed) Protein glycosylation: cellular biotechnological and analytical aspects. VCH Publishers lnc, New York, p 235-248

Noga EJ, Hartmann JX (1981) Establishment of walking catfish (Clarias batrachus) cell lines and development of a channel catfish (Ictalurus punctatus) virus vaccine. Can J Fish Aquat Sci 38:925-930

O'Reilly DR, Miller LK, Luckow VA (1992) Baculovirus expression vectors: a laboratory manual. WH Freeman Company, New York, p 1-347

Osterreider N, Wagner R, Pfeffer M, Kaaden O (1994) Expression of equine herpesvirus type 1 glycoprotein $\mathrm{gp} 14$ in Escherichia coli and insect cells: a comparative study on protein processing and humoral immune responses. J Gen Virol 75:2041-2046

Pereira L (1994) Function of glycoprotein B homologues of the family herpesviridae. Infect Agents Dis 3:9-28

Plumb JA (1973) Neutralization of channel catfish virus by serum of channel catfish. J Wildl Dis 9:324-330

Plumb JA, Thune RL, Klesius PH (1981) Detection of channel

Editorial responsibility: Jo-Ann Leong,

Corvallis, Oregon, USA catfish virus in adult fish. Dev Biol Stand 49:29-34

Reed LJ, Muench H (1938) A simple method of estimating fifty percent endpoints. Am J Hyg 27:493-497

Roizman B (1990) Herpesviridae: a brief introduction. In: Fields BN, Knipe DM (editors-in-chief) Vrology, 2nd edn. Raven Press Ltd, New York, p 841-847

Spear P (1993) Membrane fusion induced by herpes simplex virus. In: Bentz J (ed) Viral fusion mechanisms. CRC Press. Boca Raton, p 201-232

Vanderheijden N, Lecomte PC, Martial JA (1996) The attenuated V60 strain of channel catfish virus possesses a deletion in ORF50 coding for a potentially secreted glycoprotein. Virology 218:422-426

van Santen VL (1991) Characterization of the bovine herpesvirus 4 major immediate-early transcripts. J Virol 65 5211-5224

Wagner R, Liedtke S, Kretzschmar E, Geyer H, Klenk $H$ (1996) Elongation of the N-glycans of fowl plaque virus hemagglutinin expressed in Spodoptera frugiperda (Sf9) cells by co-expression of human B1, 2-N-acetylglucosaminyl-transferase I. Glycobiology 6:165-175

Walczak EM, Noga EJ, Hartmann JX (1981) Properties of a vaccine for channel catfish virus disease and a method of administration. Dev Biol Stand 49:419-429

Wang KKW, Posner A, Hajimohammedreza l (1996) Total protein extraction from cultured cells for use in electrophoresis and Western blotting. BioTech 20:662-668

Wolf K, Darlington RW (1971) Channel catfish virus: a new herpesvirus of ictalurid fish. J Virol 8:525-533

Zhang HG, Hanson LA (1995) Deletion of thymidine kinase gene attenuates channel catfish herpesvirus while maintaining infectivity. Virology 209:658-663

Submitted: January 23, 1998; Accepted: October 7, 1998

Proots received from author(s): November 26, 1998 